\title{
Etkin Otorite Yokluğunda Devlet Dışı Silahlı Aktörlerin İnsan Hakları İhlallerinden Doğan Sorumluluk Halleri
}

Burak TAŞ*

Makalenin Geliş Tarihi: 08.12.2020 Kabul Tarihi: 17.04.2021

Bu makale hakem incelemesinden geçmiştir ve TÜBİTAK-ULAKBİM Veri Tabanında indekslenmektedir.

DOI 10.30915/abd.931393

* $\quad$ Arş. Gör. / Ankara Sosyal Bilimler Üniversitesi Ceza ve Ceza Muhakemesi Hukuku Anabilim Dalı https://orcid.org/0000-0001-6481-1580 


\section{ETKIN OTORITE YOKLUĞUNDA DEVLET DIŞI SILAHLI AKTÖRLERIN INSAN HAKLARI IHLALLERINDEN DOĞAN SORUMLULUK HALLERI}

\section{Öz}

Uluslararası camia 1990'lı yıllardan beri etkin otorite yokluğu ile boğuşmaktadır. Bunun en somut örneği ise 2011 yılından bugüne Suriye'de yaşanmaktadır. Çalışmada, etkin otorite yokluğu durumunda devlet dışı silahlı aktörler tarafından gerçekleştirilen insan hakları ihlallerinden doğan sorumluluk halleri irdelenmektedir. Çalışma temel olarak üç ayrı aktör bağlamında inşa edilmiştir: İçinde bulunulan etkin otoriteden yoksun olan devlet, devlet dışı silahlı aktörlere yardım eden devlet ve son olarak doğrudan devlet dışı silahlı aktör. Çalışmada "Uluslararası Haksız Fiilden Ötürü Devletin Uluslararası Sorumluluğu” hakkındaki tasarı, örf ve adet hukuku, Birleşmiş Milletler'in organlarının kararları ve mevcut mahkeme kararları kaynak olarak kullanılmıştır. Bu husustaki hukuki düzenlemelerin etkisizliği eleştirel olarak tahlil edilmiş ve devlet dışı silahlı aktörlerin sorumluluğunu belirleme kabiliyetini haiz uluslararası mekanizmaların inşa edilmesi gerektiği üzerinde durulmuştur.

\section{Anahtar Kelimeler}

İnsan Hakları

Etkin Otorite Yokluğu

Devlet Dışı Silahlı Aktörler

Uluslararası Haksız Fiilden Ötürü Devletin Uluslararası Sorumluluğu

Suriye 


\title{
THE RESPONSIBLITY STATUS OF HUMAN RIGHTS VIOLATIONS OF ARMED NON-STATE ACTORS IN THE ABSENCE OF EFFECTIVE GOVERNMENT
}

\begin{abstract}
The international community has been struggling with the absence of effective authority since the 1990s. The most concrete example of this has been experienced in Syria since 2011. In the study, the ways of responsibility for human rights violations by armed non-state actors in the absence of effective authority is examined. Basically, the study was built in the context of three separate actors: The state lacks the effective authority, the aiding state and ultimately armed non-state actor in directly. In the study, the draft articles on "Responsibility of States for Internationally Wrongful Acts", customary law, the decisions of the bodies of the United Nations and the court decisions were used as sources. The ineffectiveness of the legal regulations in this regard has been critically analyzed and it has been emphasized that the necessity of international mechanisms which have ability to determine responsibility of armed non-state actors should be built.
\end{abstract}

\section{Keywords}

Human Rights 


\section{GiRiş}

Modern uluslararası hukukta insan hakları; devletlerin vatandaşlarına bahşettiği bir olguyu değil, insanların onur sahibi bir varlık olmaları dolayısıyla sahip olmaları gerekli olan bütün hak ve özgürlükleri ifade eder. İnsan hakları hiçbir bireyin yahut otoritenin karşı çıkamayacağı ve her durumda gözetmek durumunda olduğu en üst düzeydeki hukuksal değerlerdir. ${ }^{[1]}$ İnsanlık tarihinin gelişim sürecinde insanı esas alan bakış açıları zamanla gelişerek yaygınlık kazanmıştır. Bu gelişim tüm insanlığa yol göstererek bugünkü uygarlık düzeyine erişilmesinde büyük katkılar getirmiştir. ${ }^{[2]} \mathrm{Bu}$ bağlamda insan hakları, İnsanı insan yapan ve insandan kaynaklanan haklardır. ${ }^{[3]}$

İnsan haklarının sadece iç hukukun bir sorunu değil aynı zamanda uluslararası hukukun sorunu olması Birinci Dünya Savaşı sonrası başlamış ve İkinci Dünya Savaşı sonrasında çok yoğun olarak devam etmiştir. Birleşmiş Milletler'in (BM) kurulması ve izleyen süreçte İnsan Hakları Evrensel Beyannamesi'nin kabul edilmesiyle, insan haklarının uluslararası düzlemde korunması gerekliliği fikrinin yeşerdiği görülmektedir. ${ }^{[4]} \mathrm{Ne}$ de olsa insan haklarının etkili bir biçimde korunması, hakların düzenlenme biçimleri kadar etkili güvence mekanizmalarıyla desteklenmesine de bağlıdır. ${ }^{[5]}$

Uzunca bir süredir insan hakları ihlallerinin devletlerin iç hukuk alanını ilgilendiren ve onun egemenlik yetkileri çerçevesinde değerlendiren bir alan olduğu kabul edilmekteydi. İkinci Dünya Savaşı’nın yarattığı tahribat sonrası uluslararası camiada artık insan hakları ihlallerinin, devletlerin iç

[1] ÇEÇEN Anıl: "İnsan Hakları ve İnsancıl Hukuk", Yaşar Hukuk Dergisi, C:8 Özel Say1, Y:2013, s.809.

[2] ÇEÇEN, s.809.

[3] COŞKUN, Vahap: İnsan Hakları, Liberte Yayınları, Ankara, 2006, s.4; CAN Mücella: "İnsan Hakları ve Demokrasi Arasındaki İlişkinin Felsefi Analizi” Atatürk Üniversitesi Sosyal Bilimler Enstitüsü Dergisi, C.23, S.4, Y.2019, s.2156; ACER Yücel, KAYA İbrahim: Uluslararası Hukuk Temel Ders Kitabı, Seçkin Yayıncılık, 10. Bası, Ankara 2019, s.288.

[4] ALGAN Bülent, IŞIK Saim: Ulusal İnsan Hakları Mekanizmaları Mevzuatı, Savaş Yayınevi, Ankara 2016, s.VI.

[5] ALGAN/ IŞIK, s.VI. 
meselesi olarak değil uluslararası hukuku ilgilendiren bir mesele olarak değerlendirilmesi gerekliliği ideali belirmiştir. ${ }^{[6]}$

1990 'l y yıllarla birlikte uluslararası camia, nedenleri birçok uluslararası siyasi, ekonomik olgu ve olaylara giden etkin devlet yönetimi fenomeni ile karşılaşmıştır. Etkin otorite yokluğunun makale bağlamında en önemli görünümlerinden birisi, sorunun yaşandığı ülke içerisindeki çeşitli aktörler tarafından gerçekleştirilen insan hakları ihlalleridir. İnsan haklarının etkili bir biçimde tesis edilmeyişi ve söz konusu ihlalin devletin düşmüş olduğu sıkıntıdan kaynaklı çok geniş boyutlu olması, hem bölgesel hem de uluslararası hukukta da büyük sorunlar doğmasına neden olmuştur. ${ }^{[7]}$

Etkin devlet yönetimi yokluğunun 30 yıllık geçmişine karşın uluslararası hukukta; gerek sorunu ortadan kaldıracak gerekse söz konusu devletin eski işlerliğine kavuşana kadar ortaya çıkan sorunları bertaraf edecek hukuki mekanizmaların yaratılması çabalarının çok yetersiz olduğu görülmektedir.

Bu bağlamda en önemli eylem, etkin devlet yönetimi olgusuna uluslararası güvenliğin veya barışın tehdidi/bozulması temelinde yaklaşılmasıdır: Devletler arasında güvenlik temelli ortaya çıkan sorunlarda uygulanması için öngörülen önlem ve müdahaleleri içeren Birleşmiş Milletler Şartı'nın VII. Bölümü, yorum yoluyla etkin devlet yokluğu sorununu yaşayan devletlere uygulamaya başlamıştır. İki devletin birbiri ile sorunu bağlamında inşa edilen söz konusu düzenlemenin etkin devlet yönetimi yokluğunda bir devletin içinde var olan soruna uygulanmasının tarihi, 1990’lı yıllara dayanmaktadır. ${ }^{[8]}$ Bu bölümde "Barışın Tehdidi, Bozulması ve Saldırı Eylemi Durumunda Alınacak Önlemler” başlığı altında 39., 41. ve 42. maddelerde Güvenlik Konseyi'ne barışı yeniden tesis etmede devletlerin egemenlik

[6] PROVOST Rene: International Human Rights and Humanitarian Law, Cambridge University Press, Cambridge, 2004, s.133.

[7] PROVOST, s.58-59

[8] Dönemin BM Genel Sekreteri Boutros Boutros Ghali tarafından yazılan 1992 tarihli "An Agenda for Peace"de BM Şartının VII Bölümünün ilk kez ülke içerisindeki sorunlara uygulanacak şekilde yorumlandığı görülmektedir. Bkz. An Agenda for Peace Preventive diplomacy, peacemaking and peace-keeping: Report of the SecretaryGeneral pursuant to the statement adopted by the Summit Meeting of the Security Council on 31 January 1992, para.43, https://www.un.org/ruleoflaw/files/A_47_277. pdf (Erişim Tarihi: 21.10.2020). 
alanına müdahale yetkisi verilmiştir. ${ }^{[9]}$ Bu çerçevede söz konusu ülkelerde yaşanılan soykırım ve benzeri ağır insan hakları ihlalleri de uluslararası camiada güvenlik ve barışı bozan bir olgu olarak kabul edilmiş "insani müdahale" doktrini ${ }^{[10]}$ çerçevesinde söz konusu devlete müdahalede neden olarak gösterilmiştir.

İnsan hakları ihlallerine dair uluslararası hukukta cevabı bulunması gereken en önemli sorunlardan birisi insan hakları ihlalinde bulunan faillerin hukuki durumudur. Etkin devlet yönetimi yokluğunda insan hakları ihlallerinin failleri; söz konusu fenomenin içinde yaşandığı devlet ve etkin devlet yönetiminin yokluğu gerçeğinde ortaya çıkan diğer aktörler olarak üçüncü devletler, uluslararası örgütler, uluslararası şirketler ve devlet dışı silahlı aktörlerdir. Etkin devletin varlı̆ğ durumunda hem iç mevzuat ve hem uluslararası mevzuat insan hakları bağlamında önemli kaynaklar olarak ortaya çıkarken devlet temel yükümlü olarak sorumluluk üstlenmektedir. Buna karşın etkin devlet yönetiminin yokluğunda insan hakları ihlallerinde idari, hukuki ve cezai sorumluluğun kime atfedileceği uluslararası hukukta çok önemli bir sorun olarak yerini almaktadır.

Bu aktörler içerisinde devlet dişı silahlı aktörler (DDSA) diğerlerinden gerek iç hukuk gerekse uluslararası hukuk bağlamında tanınmayan bir olgu olması nedeniyle çok daha farklı bir yere sahiptir. Bu sorun özellikle de devlet dışı silahlı aktörlerin gerçekleştirdiği insan hakları ihlallerindeki sorumlulukta önemli bir husus olarak kendisini göstermektedir. Bu hususun dramatik bir örneğini uluslararası camia, somut olarak Suriye Devleti'nin 2011'den bugüne yaşadığ 1 etkin otorite yokluğunda tecrübe etmiştir. Suriye'nin on yıla yaklaşan etkin otorite yokluğu sürecinde, Suriye halkı çok farklı devlet dışı silahlı aktörün insan hakları ihlallerine maruz kalmıştır. Bu aktörlerin üyelerinin yargılanmasında yetkili devletin kim olduğu sorusu özellikle son

[9] Birleşmiş Milletler, BM Şartı’nın Amaçlar ve İlkeler başlıklı 1. maddesinde ırk, cinsiyet, dil ya da din ayrımı gözetmeksizin herkesin insan haklarına ve temel özgürlüklerine saygının geliştirilip güçlendirilmesinde uluslararası işbirliğini sağlamayı amaç edinmiştir.

[10] İnsani müdahale "bir devlet, devletler grubu ya da devlet-dışı aktör tarafindan, bir başka devlet topră̆ına, o devletin rizası olmaksızın, hedef devletin vatandaşlarına yönelik insancıl kaygıyla gerekçelendirilmiş askeri eylemdir". HEHIR Aidan: Humanitarian Intervention: An Introduction, Hampshire, Palgrave Macmillan, 2010, s.20. 
dönemlerde güncel bir konu olmasına karşın, bu sorundan önce tartışılması gereken en önemli husus söz konusu devlet dışı silahlı aktörlerin eylemlerinden kaynaklı hukuki sorumluğun kime ait olması gerektiği konusu göz ardı edilen bir sorundur. Gerçekte fenomenin kendi özgünlüğünde konu bağlamında belki de cevaplandırılması gereken asıl soru budur. Çünkü etkin olan bir devlette siyasi otorite hukuki olarak da sorumlu aktör olarak ortaya çıkarken, etkin devlet yönetimi yokluğunda sorumluluğun etkin olmasa da söz konusu siyasi otoritede olduğunu belirtmek çok önemli bir sorunun üstünü örtmek demektir.

Yukarıda açıklanan nedenlerle çalışmada devlet dışı silahlı aktörlerin gerçekleştirdiği insan hakları ihlallerinden ortaya çıkan hukuki sorumluluk üzerinde durulmuştur. Çalışmada öncelikle araştırmanın üzerine inşa edildiği temel kavramlardan kısaca bahsedilmiş, sonrasında devlet dışı silahlı aktörlerin etkin otorite yokluğunda insan hakları ihlallerinden dolayı aşağıdaki üç farklı aktörün sorumluluğu incelenmiştir.

a. İhlalin gerçekleştiği etkin otoriteden yoksun devletin sorumluluğu

b. Devlet dışı silahlı aktörlere yardım eden diğer bir devletin sorumluluğu

c. İhlali gerçekleştiren devlet dışı silahlı aktörün bizzat sorumluluğu

Uluslararası hukuk literatüründe DDSA’ların bireysel cezai sorumluluğu üzerine birçok çalışma olmasına rağmen hukuki sorumluluklarına yönelik bir çalışmaya rastlanılmamıştır. Bu çalışmada teamül hukukunun derlemesi niteliği taşıyan ve devletlerin hukuki sorumluğunu düzenleyen 2001 tarihli "Uluslararası Haksız Fiilden Ötürü Devletin Uluslararası Sorumluluğu" hakkındaki tasarının (2001 tarihli tasarı) ${ }^{[11]}$ ilgili hükümlerinin akıl yürütme ve yorum yoluyla DDSA'ların insan hakları ihlallerinden doğan sorumluluk hallerine uyarlanmak suretiyle literatürdeki mevcut boşluğun doldurulması

[11] Devletlerin pratikleriyle gelişen sorumluluk hukukuna ilişkin esaslar uluslararası örf adet hukuku kuralları çerçevesinde kendisine yer edinmiştir. Bu örf adet kurallarının gelişiminde ise uluslararası yargı kararları ve hakem kararları etkili olmuştur. Bu yazısız kuralların kodifiye edilmesi amacıyla yapılan çalışmalar da halen tasarı şeklinde olmakla birlikte BM Uluslararası Hukuk Komisyonu tarafından düzenlenmiştir. 2001'de Uluslararası Hukuk Komisyonu devletlerin sorumluluğu hususundaki kurallar üzerine kodifikasyon çalışmasını 59 maddelik "Devletlerin Uluslararası Hukuka Aykırı Fiillerinden Sorumluluğu” adıyla oluşturmuştur 
hedeflenmiştir. Böylece Suriye coğrafyasında mevcut insanlık krizinin giderilmesi için işlevselleştirilmesi gereken sorumluluk mekanizmalarından birini oluşturan hukuki sorumluluğun kapsamı belirlenerek literatüre bir katkı sağlanması amaçlanmaktadır.

\section{ETKIN OTORITE YOKLUĞU, DEVLET DIŞI AKTÖRLER VE HUKUKi SORUMLULUK KAVRAMLARI}

Çalışmanın inşa edildiği kavramlar ve olgular uluslararası camianın 1990 yılından sonra çok yoğun olarak uğraştığı kavramlardır. Bu kavramlar ve olgular sırasıyla uluslararası ilişkilerde "başarısız devlet" kavramı ve konsepti bağlamında sunulan etkin otorite yokluğu, devlet dışı silahlı aktörler ve hukuki sorumluluktur.

\section{A. Etkin Otorite Yokluğu}

Uluslararası hukuk teamülüne göre devletin unsurları üstün siyasi otorite, insan topluluğu ve ülkedir. Devletlerin Hakları ve Görevlerine İlişkin Montevideo Sözleşmesi'nin birinci maddesine göre bir uluslararası hukuk kişisi olan devletin, devlet olarak değerlendirilebilmesi için gerekli nitelikler sayılmıştır. Bunlar sırasıyla: sürekli bir halk topluluğu, sınırları belirlenmiş bir toprak parçası, üstün otorite (government) ve diğer ülkelerle ilişkiye girme kapasitesidir. ${ }^{[12]}$ Burada üstün siyasi otorite olarak tanımlanan olgunun en önemli vasfi; bir devletin kurulma aşamasında egemenlik iken var olan bir devlette ise etkin otoriteye sahip olma durumu olarak ortaya çımaktadır. Bir başka deyiş ile etkin devlet yönetimi, halihazırda kurulmuş bulunan bir devletin sahip olduğu bir yetiyi, hükümet edebilme kapasitesini ifade etmektedir. Montevideo Sözleşmesi'nin 1. maddesinin son fikrası bu bağlamda hem egemenlik olgusunun hem de etkin devlet otoritesinin dış görünümünü teyit etmektedir. ${ }^{[13]}$

Yukarıda da belirtildiği üzere uluslararası camia; etkin otorite yokluğu olgusu ile boğuşan devletlerle, Soğuk Savaş’ın sona ermesinin ardından

[12] Montevideo Convention, https://www.ilsa.org/Jessup/Jessup15/Montevideo\%20 Convention.pdf (Erişim Tarihi: 28.10.2019).

[13] AKPINARLI Neyire: Fragility of the 'Failed State' Paradigm, Martinus Nijhoff Publishers, Leiden Boston, 2010, s.7. 
yoğun olarak karşılaşmıştır. ${ }^{[14]}$ Söz konusu devletlerin tarihsel geçmişlerinde üç unsur onların ortak paydası olarak karşımıza çıkmaktadır: bir zamanlar sömürge veya manda yönetimi altında olmaları, Soğuk Savaş döneminde vekâlet savaşlarına mekan olmaları ve son olarak da neo-liberal politikaların dayatıldığı topraklar olmalarıdır. Söz konusu olguya, 1992 yılında ABD’nin dış politikalarına meşruiyet kazandırma amacıyla icat ettiği başarısız devlet kavramı ve yine bu kavram altında inşa edilen konsept bağlamında çözüm önerileri sunulmuştur. Fenomenin nedenlerini ve niçinlerini açıklamayan "başarısız devlet" kavramı, mağduru suçlu gösterme durumunun bir görünümüdür. Konsept, bu olgunun nasıl ortaya çıktığı ile ilgilenmemiştir. Mevcut fenomeni temel olarak, "bu devletlerin kendilerini yönetmeyi bilmedikleri için uluslararası camianın askeri müdahale de dahil bu ülkelere müdahale etme ve onlara yönetmeyi öğretme hakkı ve yükümlülügü vardır” üzerine inşa edilmiştir. Başarısız devlet kavramı, sadece kendileri için pragmatik olanı seçen emperyalist devletlerin kavram mühendisliği örneklerinden sadece birisidir. Bu açıdan bakıldığında başarısız devlet kavramının kullanılmaması gerekliliği her şeyden öte uluslararası toplumun menfaatine olacaktır. ${ }^{[15]}$

Başarısız devlet kavramı statüsel bir kavramı temsil etmemekle birlikte mevcut bir olguyu ifade etmektedir. Olması gereken, başarısız devlet kavramı ile bir devletin belli bir statüye sokulmaması ve mevcut ve fiili durumu ifade eden etkin otorite yokluğu kavramının kullanılmasıdır.

Etkin otorite yokluğu fenomeninin en önemli görünümleri devlet fonksiyonlarını çeşitli nedenlerle yerine getiremeyen bir otoritenin varlığ ve bunun sonucunda da insan hakları, terör, mülteci sorunu gibi birçok gerek iç hukuk gerekse de uluslararası hukuk bakımından sıkıntılı konuların ortaya çıkmasıdır. ${ }^{[16]} \mathrm{Bu}$ sıkıntıların bir boyutu da etkin otorite yokluğunda insan hakları ihlallerinde sorumluluk hususunun nasıl bir değişiklik arz edeceğidir.

\section{[14] AKPINARLI, s.1.}

[15] Aynı yönde bkz. AKPINARLI, s.87-103; ÖĞÜT Selman: "Başarısız Devlet Kavramının İncelenmesi”, Marmara Üniversitesi Hukuk Fakültesi Hukuk Araştırmaları Dergisi, C.19, S.3, Y.2013, s.172-173; LOWE Vaughan: International Law, Clarendon Law Series, Oxford: Oxford University Press, 2007, s.114

[16] ROTBERG Robert I.: State Failure and State Weakness in a Time of Terror, World Peace Foundation, Brookings Institution Press, Cambridge Massachusetts 2003, s.5-6. 


\section{B. Devlet Dışı Silahlı Aktörler}

Devlet insanoğlunun tarihinde çok uzun bir dönem hem uluslararası ilişkiler ve uluslararası hukukta tek aktör iken bugün devletin yanında uluslararası örgütlerden uluslararası sivil toplum kuruluşlarına ve uluslararası şirketlere birçok aktör ortaya çıkmıştır. Bu aktörlerden bir diğeri de devlet dışı silahlı aktördür.

"Devlet dışı silahlı gruplar kökten dinci ilkeleri savunanlardan ırkçı militan gruplara, özgürlük savaşçılarından devrimci silahlı muhalif gruplara kadar birbirlerinden farklı saikleri haiz geniş bir yelpazedeki aktörü ihtiva etmektedir." ${ }^{[17]}$ Devletlerin, uluslararası insan hakları hukuku bağlamında artık uluslararası hukukun tek asli süjesi olmaması sebebiyle, devlet dışı aktörlerin uluslararası hukuktaki konumu eskiden olduğundan çok daha fazla önem arz eder hale gelmiştir.

Devlet dışı silahlı aktörlerin en aktif oldukları yer ise etkin devlet yönetiminin olmadığı ülkelerdir. Bu durumu Afganistan'dan Irak'a ve Suriye'ye uzanan yelpazede görmek mümkündür. Hükümetin ülkesinde otoritesini kaybetmesi, devletini etkili olarak yönetme yetkisini kullanma yetisinden kısmen de olsa mahrum kalması, devlet içinde birçok hukuk dışı organizmaların vücut bulmasına sebebiyet vermektedir. Bu organizmaların bazıları terörü araç olarak kullanan organizmalar niteliğinde iken bazıları ise muhalif bağımsız gruplar niteliğindedir. ${ }^{[18]}$

DDSA'lar ağır ve sistematik insan hakları ihlallerinde bulunarak uluslararası barış ve güvenliği tehdit eder bir hal almışlardır. Birçok uluslararası organizasyon, DDSA’ların gerçekleştirdiği insan hakları ihlallerini kategorize etmiştir. Özellikle BM Uluslararası Soruşturma Komisyonu DDSA’ların uymaları gereken teamülkurallarını sıralarken aslında DDSA'ların gerçekleştirdiği insan hakları ihlallerinin de tespitini yapmış bulunmaktadır. Bu ihlaller: sivillerle savaşçılar arasında ayrım yapmama; sivillere kasıtlı saldırı; sivilleri terörize etmeyi amaçlayan saldırı; işkence, gayriinsani ya da kötü muamele; sivillerin zorla göç ettirilmesi; rehin alma; yağma; sivillere ayırım

[17] YEŞİLTAŞ Murat, DURAN Burhanettin: Ortadoğu’da Devlet Dişı Silahlı Aktörler, Seta Kitapları, İstanbul 2018, s.33.

[18] YEŞİLTAŞ/DURAN, s. 33-34. 
gözetmeyen saldırı; düşman savaşçılara kötü muamele; kültürel bina ve nesnelere saldırı şeklinde sıralanarak devam etmektedir. ${ }^{[19]}$

Etkili devlet yönetimi yetkisini kısmen dahi olsa kaybetmesi durumunda devlet içindeki hukuk dışı yapılanmalardan terörü araç olarak kullanan oluşumlar kendi ideolojilerinden hareketle haklılıklarını ispat etme ve bölgedeki halkı kontrol altında tutmak amaçlı sivil halk üzerinde sistemli olarak ağır insan hakları ihlallerinde bulunmuşlardır. Bir DDSA olarak varlık gösteren YPG/PYD (Halk Savunma Birlikleri/Demokratik Birlik Partisi) ve DEAŞ (Devlet' ül Irak ve'ş Şam), Suriye'deki kaotik ortamda birçok ağır insan hakları ihlallerinde bulunmaktadır. Suriye'de ABD destekli YPG/PYD örneğinde somut verilere ulaşılabilmektedir. Amnesty International verilerine göre köyleri, kasabaları tahrip eden, yıkan ve yakan; yerel halkı bulunduğu yerden zorla göçe zorlayan, evlerinden zorla çıkarıp bu evleri yakan ve DEAŞ ile mücadele adı altında ABD'nin kendisine verdiği desteğe güvenerek sivillere yönelik insan hakları ihlallerinde bulunan bu yapılanmanın eylemleri savaş suçu oluşturmakta ve bu açıdan bakıldığında bu eylemler özü itibarıyla ağır insan hakları ihlalleri teşkil etmektedir. ${ }^{[20]}$

YPG/PYD'nin gerçekleştirdiği ağır insan hakları ihlallerine ek olarak DEAŞ da ağır insan hakları ihlallerinde bulunmakla birlikte DEAŞ’in haksız eylemleri, DDSA'larnın bizzat sorumluluğu hususunda ayrıca değerlendirilecektir.

\section{Hukuki Sorumluluk}

Uluslararası hukuk minvalinde hukuki sorumluluk, devletlerin tarihsel gerçeklikten kaynaklı teamül hukukunda yükümlülüklerini yerine getirmemesi, ihlalin hukuki bir sonuç doğurması ve bu sonucun devletin sorumluluğunu

[19] Report of the International Commission of Inquiry on Darfur to the United Nations Secretary-General-Pursuant to Security Council Resolution 1564 of 18 September 2004, Geneva, 25 January 2005, para.166, http://www.un.org/news/dh/sudan/ com_inq_darfur.pdf (Erişim Tarihi: 28.12.2019).

[20] Syria: US ally's razing of villages amounts to war crimes, https://www.amnesty.org/ en/latest/news/2015/10/syria-us-allys-razing-of-villages-amounts-to-war-crimes/, October 2015, (Erişim Tarihi: 1.1.2020). 
doğurması olarak karşımıza çıkmaktadır. ${ }^{[21]}$ Hukuki sorumluluk, cezai sorumluluktan farklı olarak devletleri belirli bir yönde davranmaya zorlayacak ya da mahkûm edecek nitelikte maddi bir yaptırım içermez. Kaldı ki BM Şartı ekseninde devletlerin egemenliği prensibi çerçevesinde uluslararası hukukta devlet, cezai sorumluluğun faili kılınıp yargılanamaz. ${ }^{[22]}$ Özü itibarıyla hukuki sorumluluk, uluslararası hukukun süjelerini hesap verebilir kılmaktadır. ${ }^{[23]}$ $\mathrm{Bu}$ açıdan hesap verebilir kılınma, uluslararası hukukta değişik şekillerde karşımıza çıkabilir.

Hukuki sorumlulukta uluslararası hukuka aykırılık sadece tespit edilmiş olur; devlet, maddi bir yaptırımla doğrudan bağlanamaz. Ancak bireylerin insan hakları ihlal edildiğinde bu ihlalin ortadan kaldırılması ve bireylerin menfaatlerinin temini noktasında hukuki sorumluluk, tespit edici yönüyle devletleri doğrudan etkilemektedir. Uluslararası kamuoyu oluşturmada ve devletler ile terör örgütleri arasına mesafe koyulması gerekliliği temelinde hukuki sorumluluk önemli bir işlevi yerine getirebilecektir. Böylece teröre destek veren devletler, uluslararası kamuoyu önünde hesap verebilir konuma sokulabilecektir.

DDSA'nın eylemlerinden doğan hukuki sorumluluk, hem insan hakları ihlallerinin gerçekleştiği devletin, hem söz konusu aktörü destekleyen devletin hem de DDSA'nın bizzat sorumluluğunu içermektedir.

DDSA'nın içinde bulunduğu devletin ve kendisini destekleyen devletin sorumluluğu bağlamında kaynaklar 2001 tarihli tasarının ilgili hükümleri, teamül hukuku, uluslararası hukukun genel ilkeleri ve teamül kaynaklı uluslararası mahkeme ve hakem kararlarıdır.

2001 tarihli tasarının ilk maddesinde uluslararası hukukun genel ilkelerinden olan "Devletlerin her uluslararası hukuka aykırı fiili o devletin

[21] BAL Ali: Devletin Uluslararası Sorumluluğunun Doğması, 2006 http://acikerisim. deu.edu.tr:8080/xmlui/bitstream/handle/20.500.12397/11843/189480. pdf? sequence $=1$ \&isAllowed $=y$ (Erişim Tarihi: 25.1 .2020$)$.

[22] ACER, KAYA, s.366.

[23] D'ASPREMONT Jean, NOLLKAEMPER Andre', PLAKOKEFALOS Ilias; RYNGAERT Cedric: "Sharing Responsibility Between Non-State Actors and States in International Law: Introduction”, Neth Int Law Rev (2015) 62:49-67, s.54, https:// link.springer.com/article/10.1007/s40802-015-0015-0 (Erişim Tarihi: 19.11.2019). 
uluslararası sorumluluğunu beraberinde getirir" ilkesi tasarıda kendisine yer edinmiştir. ${ }^{[2]}$ Bu ilkeyi ilk maddesinde ihtiva etmekle tasarı sorumluluk hukukuna ilişkin temel felsefesini ortaya koymuştur.

Bu düzenleme temelde iki veya daha fazla devlet arasındaki ihtilaf için öngörülmüştür. Ancak uluslararası hukukun dinamik yapısı nedeniyle söz konusu tasarı çağın koşullarına cevap verecek nitelikte düzenlemeler bakımından yetersiz kalmaktır. DDSA'ların hukuki sorumluluğuna ilişkin yargıya varabilmek için devletlerin sorumluluğunu düzenleyen tasarının ilgili maddeleri, olması gereken hukuk bağlamında amaca uygun şekilde yorumlanırsa bu yetersizlik giderilebilecektir.

Devletin hukuki sorumluluğuna yönelik olarak örf ve adet hukukunda, mahkeme kararlarında ve tasarıdaki kuralların yanı sıra BM'nin organlarının bazı kararlarında da sorumluluğa ilişkin bazı veriler mevcuttur. DDSA'ların bizzat kendi sorumluluğu bağlamında kaynak mevcudiyeti ise problem arz etmektedir. Bu noktada ilgili tasarı hükümlerinin yorumlanması ve ilgili mahkeme kararları bakımından akıl yürütme yolu ile sorumluluk hususunun açıklığa kavuşturulması mümkündür.

\section{DEVLET DIŞI SILAHLI AKTÖRLERIN INSSAN HAKLARI IHLALLERININ SORUMLULARI}

Devlet dışı silahlı aktörlerin etkin otorite yokluğunda ciddi anlamda insan hakları ihlalleri gerçekleştirdiği gerçeği karşısında hukuki sorumluluk, önemli bir husus olarak uluslararası hukukta yerini almaktadır. Burada hukuki sorumluluk üç farklı açıdan inceleme yapılmasını zorunlu kılmaktadır. Birinci olgu devlet dışı silahlı aktörün içinde bulunduğu devletin sorumluluğunun ne olduğu sorusudur. İkinci önemli husus söz konusu devlet dişı silahlı aktörü destekleyen devletin sorumluluğunun ne olduğudur. Son olarak ise devlet dışı silahlı aktörün insan hakları ihlalinden doğan doğrudan sorumluluğudur.

[24] Draft Articles On Responsibility Of States for Internationally Wrongful Acts, With Commentaries, Yearbook Of The International Law Commission, 2001, Volume II, Part 2, s.32. https://legal.un.org/ilc/publications/yearbooks/english/ilc_2001_ v2_p2.pdf (Erişim Tarihi: 11.11.2019). 


\section{A. İhlalin Gerçekleştiği Devletin Sorumluluğu}

Etkin otoritenin varlığında ve yokluğunda sorumluluk hususu değişiklik arz etmektedir. Bu değişiklik, DDSA'ların gerçekleştirdiği insan hakları ihlallerinden doğan sorumluluğun devlete izafe edilip edilemeyeceği noktasındadır. Etkin bir otoritenin varlı̆̆ında insan haklarının ihlalinin gerçekleştiği devletler, egemen oldukları kendi toprakları içinde gerçekleşen her türlü ihlalden sorumludur. Bu sorumluluk hem iç hukuktan kaynaklanmaktadır, hem de uluslararası hukuktan. Uluslararası hukukta devletlerin sorumluluğuna ilişkin bir teamül hukuku kuralı bulunmaktadır ve bu kural 2001 tarihli tasarının birinci maddesinde de "bir devletin uluslararası hukuka aykırı fiili, o devletin sorumluluğunu doğurur" şeklinde kendisine yer edinmiştir.

Etkin devlet yönetiminin yokluğunda ise sorumluluğun kime ait olacağ meselesi önemli bir husus olarak karşımıza çıkmaktadır. Uluslararası hukukta bu bağlamda kaynak olarak kullanabileceğimiz enstrümanlar: teamül hukukunun akıl yürütme yoluyla değerlendirilmesi, tasarı halindeki maddeler ve mahkeme kararlarıdır.

2001 tarihli taslak, ihlalin gerçekleştiği devleti DDSA'ların eylemlerinden dolayı sorumlu kılmaktadır. Özellikle 9. ve 10. maddeleri çerçevesinde devlet dışı aktörlerin eylemleri dolayısıyla dolaylı olarak sorumlu kılmaktadır. ${ }^{[25]}$ “Bir Davranışın Devlete İsnad Edilebilmesi” başlıklı ikinci Bab’ın altındaki 9. maddede etkin otorite yokluğunda devletlerin devlet dışı silahlı aktörlerin fiillerinden dolayı sorumluluğu konusu açıklığa kavuşturulmaktadır. Tasarının resmi otoritelerin yokluğunda ya da yetersizliği halindeki davranış başlıklı 9. maddesi şu şekildedir:

"Bir kişinin ya da bir grup kişinin davranışı, şayet bu kişi ya da grup, resmi otoritelerin yokluğunda ya da yetersizliği halinde, kamu gücü yetkilerini kullanıyorsa ve koşullar bu yetkilerin kullanılmasını gerektiriyorsa, milletlerarası hukuka göre Devletin fiili olarak kabul edilir."[26]

Söz konusu maddede görüldüğü üzere genel olarak davranışın Devlet'e isnat edilebilmesi hususunda üç tane şartın varlığı aranmaktadır. İlk şart davranışın kamu gücünün kullanılması niteliğinde olmasıdır. İkinci şart, bu fiillerin resmi otoritelerin yokluğunda gerçekleşmesidir. Üçüncü şart ise,

\section{[25] TAŞDEMİR, s.76.}

[26] ERKİNER, s.309. 
o anki durumun ve koşulların bu yetkiyi kullanmayı gerektirmesi olarak belirtilebilir. ${ }^{[2]}$ Tasarının 9. maddesinin şerhinde, etkin otoritenin yokluğunda, kamu gücü yetkileri kullananın değil; bu fiillerden -gerekli şartların varlığında- devletin sorumlu olacağı belirtilmiştir. ${ }^{[28]}$ Ancak asıl önemli olan nokta şu hususta kendisini göstermektedir: 9. maddenin temelinde yatan prensip, idare hukukundaki fiili memur teorisidir. Bu teoriye göre, herhangi bir olağanüstü durumda devlet organlarının müdahalesinin bulunamayacağı hallerde kişiler veya kişi topluluklarının o şartlar altındaki fiilleri, devletin yetkili organlarının fiili sayılabilecek ve bu kişilerin fiilleri eğer hukuka aykırı ise devlet memurunun fiili hukuka aykırıymış̧̧asına devlete isnat edilebilecektir. ${ }^{[29]}$ Ancak mevcut çalışma bağlamında 9. madde, maddenin şerhinde belirtildiği şekilde yorumlandığında, etkin otoritenin yokluğunda devlet dışı silahlı aktörün uluslararası hukuka aykırı eylemden sorumluluğu meselesine cevap vermemektedir. Ancak 9. madde, 10. maddenin 3. fikrası ile beraber değerlendirildiğinde bu sorunun aşıldığı görülmektedir. Şöyle ki:

Madde 10/3: "Bu madde, 4. maddeden 9. maddeye kadar olan maddeler uyarmca, devletin fiili olarak kabul edilmesi gereken bütün davranışların, bunlar herhangi bir biçimde isyan hareketinin davranışlarına bağl olmuş olsa da, devlete isnat edilmesine engel olmaz."[30]

Bu maddeden anlaşılan odur ki; 9. madde sadece fiili memur teorisi bağlamında anlaşılmayıp aynı zamanda "isyan hareketleri" sonucu gerçekleşen ihlallerden de sorumluluk hususunda gündeme gelebilecektir. Böylece etkin otoritenin olmadığı bir düzlemde isyan hareketi gerçekleştiren DDSA'ların insan hakları ihlallerinde devletin sorumluluğu, 9. madde çerçevesinde değerlendirilebilecektir.

[27] ERKİNER Hakkı Hakan: Devletin Haksız Fiilden Kaynaklanan Uluslararası Sorumluluğu, Oniki Levha Yayınları Ankara 2010, s.142.

[28] Responsibility Of States For Internationally Wrongful Acts, With Commentaries, s.49.

[29] Responsibility Of States For Internationally Wrongful Acts, With Commentaries, s.49.

[30] ERKINER, s.143. 
9. madde ve 10. madde beraber değerlendirildiğinde 1903 'teki Bolivar Railway Company Davası ${ }^{[31]}$ özel olarak incelenmeye değerdir. Bolivar Railway Company Davasını incelemeye değer kılan husus, bu davada etkin otorite yokluğunda olması gerekene yönelik bir yargıda bulunulmuş olmasıdır. Söz konusu davada isyan hareketinin başarıya ulaşma ve ulaşmama durumu üzerinde iki temel yargıya ulaşılmıştır.

Söz konusu davada komisyona göre, başarıya ulaşan bir devrim sonunda baştan itibaren işlenen fiillerden devlet sorumlu olacaktır. Bu yargısını ise isyanın artık başından beri (ab inito) o milletin iradesini temsil ettiği noktasında temellendirmektedir. ${ }^{[32]}$ Burada aslında komisyon üyeleri açıkça temellendirmese dahi devletlerin sürekliliği ilkesinden hareket etmiştir. Çünkü aslolan devletin varlığıdır; kurumlar baki, kişiler geçicidir. Bu ilkeye göre hükümetler geçici olduğundan sorumluluğun asıl muhatabı devlet olabilmektedir.

İsyanın başarıya ulaşmadığı hallerde ise İngiltere-Venezuela Karma Komisyonu, devletin otoritesinin fiilen ve sürekli bir biçimde etkili olmadığ yerde, başka bir ifadeyle devletin kontrolü altında olmayan yerde hukuka aykırı fiiller nedeniyle devletin sorumlu olmayacağını belirtmektedir. ${ }^{[33]}$

Bolivar-Railway Davasının bir benzerini Avrupa İnsan Hakları Mahkemesi'nin (AİHM) 1996 tarihli Loizidou Kararı'nda görmekteyiz. AİHM Loizidou Kararı'nda ${ }^{[34]}$ Avrupa İnsan Hakları Mahkemesi'nin, Avrupa İnsan Hakları Sözleşmesi' nin (AİHS) 1. maddesindeki “yargı yetkisi” kavramının sözleşmeci devletlerin ulusal topraklarıyla sınırlı olmadığını belirttikten sonra şöyle devam etmiştir: "Sözleşmeci devletlerin toprakları dışında sonuçlar doğuran eylemleri kendi yetkili makamları tarafından yapıldığı için, bu eylemler ulusal sınırları içinde ya da dışında yapılsın, sözleşmeci devletlerin

[31] Great Britain v. Venezuela 13 February 1903 pdf HOUGHTON N.D. "The Responsibility of the State for the Acts and Obligations of Local De Facto Governments and Revolutionists", Minnesota Law Review, 1990, s. 253. https://core.ac.uk/ download/pdf/217207587 (Erişim Tarihi: 20.10.2020).

[32] YEŞILTTAŞ, DURAN, s.191.

[33] YEŞİLTAŞ, DURAN, s.190.

[34] Loizidou v. Turkey, Report of the Commission, adopted on 8 July 1993. http://www. hudoc.echr.coe.int (Erişim Tarihi: 20.10.2020). 
sorumluluğu ortaya çıkabilir". ${ }^{[35]}$ Söz konusu kararda mahkeme, KKTC’de bulunan Türk askeri sayısından hareketle "etkin kontrol uygulayan otorite" olarak Türkiye'yi işaret etmiş ve AİHS'in 1. maddesindeki yargı yetkisi terimini geniş yorumlayarak KKTC topraklarını Türkiye'nin yetki alanı içinde kabul ederek, burada ortaya çıkacak Sözleşme ihlalleri bakımından sorumluluğun KKTC'ye değil, etkin kontrol uygulayan Türkiye'ye yüklenebileceğini hükme bağlamıştır. ${ }^{[36]}$ Görülüyor ki AİHM burada etkin kontrol kıstasıyla insan hakları ihlalinin gerçekleştiği toprak parçasında yer alan devleti değil, devlette etkin kontrol uygulayan devleti ihlalin faili kılmıştır. Sonuçta, ihlalin gerçekleştiği devletin dışında başka bir devlet de insan hakları ihlalinden dolayı, mahkemeye göre sorumlu olabilmektedir. Yukarıda bahsedilen iki mahkeme kararı ile tasarı arasındaki bu farklılık, egemenlik ile etkin otorite arasındaki farklılıkta yatmaktadır. 1903'lü yıllar egemenlik ve etkin otorite kavramlarının birbiri içine geçtiği yıllar idi. Zamanın şartları, etkin otorite ile egemenlik yetisinin birbirinden ayrılması gerekliliğini gerektirmiyordu. Farkındalığın zaman içinde gelişimi üzerine 2001 tarihli tasarının söz konusu mahkeme kararından farklılık arz etmesi pek de yadırganacak bir durum değildir. Çünkü bir devlet, ülkesinde etkin otoritesini kaybetmekle egemen olma kudretini kaybetmemektedir. Egemenlik kudreti, etkin otoriteyi de içine alan bir üst kavramdır ve etkili devlet yönetimi, egemenlik kudretinin somut bir tezahürüdür. Hakeza İbn-i Haldun da otorite yetisini egemenlik kudretin bir unsuru olarak görmekteydi. ${ }^{[37]}$

Tasarının 9. maddesi, 10. maddesinin 3. fikrası birlikte değerlendirildiğinde DEAŞ ve YPG/PYD gibi ülkesindeki devlet dışı silahlı aktörlerin devletmişçesine devlet erkinden kaynaklanan yetkileri kullanırken insan hakları ihlallerinde bulunduklarında, bu ihlallerden dolayı Suriye sorumlu tutulabilecektir. Ancak Bolivar-Railway Company Davası'nda komisyonun vardığ yargı ile AİHM'nin Loizidou Kararı tam tersi bir sonucu ifade etmektedir.

[35] DEREBOYLULAR Özde, ARMAN Perçem: Avrupa İnsan Hakları Mahkemesinin Kıbrıs'la İlgili Verdiği Kararların KKTC ve Türkiye’ye Etkisi, s.310, http://tbbdergisi. barobirlik.org.tr/m2018-136-1777 (Erişim Tarihi: 29.10.2019).

[36] DEREBOYLULAR, ARMAN, s.308-309.

[37] YAŞAR Ali: İbni Haldun'a Göre Siyasi Otorite ve Liderlik, Genç Hukukçular Hukuk Okumaları, s.2, http://www.muharrembalci.com/hukukdunyasi/makaleler/ birikimlerV/610.pdf (Erişim Tarihi: 20.12.2019). 
Etkin otorite yokluğunun Suriye konjonktüründe doğurduğu anarşik ortamın ve Suriye coğrafyasında aktörler arasındaki iletişim kopukluğunun insan hakları ihlali konusunda yarattığı etki değerlendirilmeden, doğrudan devleti sorumlu kılmak ne kadar doğrudur? Nitekim sorumluluk hukukunun temeli kınanabilirliğin varlığıdır. Suriye Devleti bizzat gerçekleştirdiği insan hakları ihlallerinden tasarıya göre elbette sorumlu tutulabilecektir. Ancak Suriye'de etkin otoritenin yokluğundan faydalanarak anarşik eylemlerde bulunup siviller üzerinde insan hakları ihlalleri gerçekleştiren YPG/PYD ve DEAŞ gibi DDSA'ların fiillerinden Suriye'nin sorumlu tutulmasının ahlaki kınanabilirlik kriteri bakımından ne kadar yerinde olduğu tartışılabilir. ${ }^{[38]}$

Tasarının öngördüğü şekilde, devlet dışı silahlı aktörlerin fiillerinin, ihlalin gerçekleştiği devlete isnat edilmesi kuralı, sorumluluk yükleme mekanizması bakımından sonuçsuz kalabilecektir. ${ }^{[39]}$ DDSA'ları insan hakları ihlallerinden sorumlu tutmaya yönelik devletin sorumluluk kanalları, DDSA'ları hesap verebilir kılmada oldukça yetersiz kalabilecek ve zor olabilecek; aynı zamanda etkin otorite yokluğunda da bu durum imkansız olabilecektir. ${ }^{[40]}$

Sonuç olarak Boilvar-Railway Company Davası ile AİHM'nin Loizidou Davası'nda mahkemenin verdiği karar aslında var olan teamül kuralının bir tespiti niteliğindedir. Bu açıdan bakıldığında belki de söz konusu tasarı olması gerekene yönelik bir teamül hukuku kuralını içermemektedir. Hal böyle olunca, kınanabilirlik hususu açısından değerlendirildiğinde, ülkesinde geçici olarak etkin otoritesini kaybetmiş bir devletin; ülkesinde DDSA’larca gerçekleştirilen insan hakları ihlallerinden sorumlu olmaması gerekmektedir.

\section{B. DDSA'ları Destekleyen Diğer Devletlerin Sorumluluğu}

DDSA'ların insan hakları ihlalinden doğan sorumluluk bağlamında değerlendirilmesi gereken ikinci tür aktör devlet dışı silahlı aktörleri destekleyen üçüncü bir devlettir. Burada özellik arz eden durum ise etkin devlet yönetiminin yokluğu sürecinde devlet dışı silahlı örgütlerin bir üçüncü devlet tarafından desteklenmesi halidir. Mesela YPG/PYD’nin ABD, Özgür Suriye

[38] Kınanabilirlik kriteri ile ilgili geniş bilgi için ve kınanabilirlik ile kusur ilkesi arası ilişki için bkz. Hamide Zafer, Ceza Hukuku Genel Hükümler (TCK m. 1-75), Beta Yayıncılık, 7. Baskı, İstanbul 2019, s.52-54.

[39] D'ASPREMONT; NOLLKAEMPER; PLAKOKEFALOS; Ryngaert, s.54.

[40] D'ASPREMONT; NOLLKAEMPER; PLAKOKEFALOS; RYNGAERT, s.54. 
Ordusu'nun (ÖSO) Türkiye tarafından desteklenmesi durumudur. ${ }^{[41]}$ Söz konusu örgütlerin insan hakları ihlalinde bulunması durumunda sorumluluğun kime ait olacağı önemli bir sorudur. Tasarının 8. ve 11. maddelerinin bu bağlamda incelenmesi gerekmektedir. Bu maddeler de ihlalin gerçekleştiği devletin dışındaki başka bir devleti, devlet dışı aktörlerin eylemleri dolayısıyla dolaylı olarak sorumlu kılmaktadır. ${ }^{[42]}$

Tasarının devlet tarafından kendisinin olarak tanınan ve benimsenen davranış başlıklı 11. maddesi devleti şu şekilde sorumlu tutmaktadır:

“Önceki maddelere göre devlete isnat edilemeyen bir davranış, bu devlet tarafindan söz konusu davranışın kendi davranışı olarak tanındiğı ve benimsendiği halde ve ölçüde, milletlerarası hukuka göre bu devletin fiili olarak kabul edilir." [43]

Maddeden açıkça anlaşıldığı üzere devletin kendi gerçekleştirmese ve bu fiillere bir katkısı bulunmasa bile bu ihlalleri benimsemesi durumunda sorumluluğu söz konusu olmaktadır. Bu duruma örnek olarak İtalya’daki Roma Askeri Mahkemesi'nin 1996'da Priebke Davasi ${ }^{[44]}$ kararı gösterilmektedir. Mahkeme kararında; partizanların İtalya'nın resmi statüsündeki savaşanları olmamasına rağmen bu devletin söz konusu grubun Alman askerlerine karşı gerçekleştirdiği saldırıları teşvik etmesi ve çatışmaların

[41] Türkiye Cumhuriyeti, Fırat Kalkanı Harekâtı kapsamında 28 Eylül 2016 tarihli Milli Güvenlik Kurulu (MGK) Basın Bildirisinde, "hudutlarımızda bir terör koridorunun oluşmaması için başlatılan Fırat Kalkan Harekâtının öncelikli iki amacından ilkinin, sınır güvenliğimizin sağlanması ve bölgede yaşayanların can ve mal güvenliğinin temin edilmesi; ikincisinin ise, buradaki DEAŞ ile PYD/YPG terör unsurlarnın bütünüyle temizlenmesi ve ülkelerinin bütünlü̈̆̈̈ için Özgür Suriye Ordusunun desteklenmesi olduğu" ifade edilmiştir. 28 Eylül 2016 tarihli MGK Basın Bildirisi, para.5. http://www.mgk.gov.tr/index.php/28-eyluel-2016-tarihli-toplantı Erişim Tarihi: 20.10 .2020 .

[42] TAŞDEMİR Fatma: "Devlet Merkezli Uluslararası Hukuk Sistemi Ve Devlet Dışı Silâhı Aktörler”, İ.Ü. Siyasal Bilgiler Fakültesi Dergisi, No:56, Mart 2017, ss.59-85, s.76, https://dergipark.org.tr/tr/download/article-file/329011 (Erişim Tarihi: 24.10 .2019$)$.

[43] ERKINER, s.310.

[44] Hass and Priebke case in 1997, https://ihl-databases.icrc.org/applic/ihl/ihl-nat.nsf/ 0/83344FFD0508802AC125765B004B9E54 (Erişim Tarihi: 20.10.2020). 
sona ermesinden sonra partizanların resmi olarak tanınması nedenlerinden dolayı hukuka aykırı fiillerin İtalya’ya atfedilebileceği belirtilerek uluslararası sorumlu olduğuna karar vermiştir. ${ }^{[45]}$

Tasarının devletin yönlendirmesi ya da denetimi altında iken davranış başlıklı 8. maddesi: "Bir kişinin ya da bir grup kişinin davranışı, şayet bu kişi ya da grup bu davranısı yaparken, devletin talimatlar, emri ya da denetimi altında ise, milletlerarası hukuka göre devletin fiili olarak kabul edilir." [46] diyerek devleti, devlet dışı aktörlerin fiillerinden sorumlu tutmuştur. Burada lafzi yorum yapıldığında kastedilen, ihlallerin gerçekleştiği devlette yer alıp bu devletin talimatlarıyla ihlallerde bulunan bu örgütlenmenin fiillerinin bizatihi o devlete izafe edileceğidir ${ }^{[47]}$. Ancak ortada insan hakları ihlali gibi uluslararası hukuku derinden etkileyen bir mesele olduğu için böylesi durumda 8. madde geniş yorumlanarak, ihlalin gerçekleştiği devlet dışındaki başka bir devletin yönlendirmesi ile insan hakları ihlallerinde bulunan DDSA'ların fiillerinden doğan sorumluluk, bu devlete izafe edilebilecektir. De lege feranda bir yorumla ulaşılan bu sonuç, insan haklarının dokunulmazlığı hususunda uluslararası toplumun menfaatlerine uygun olacaktır.

Son tahlilde bu başlık altında değerlendirilen sorumluluk türüne en önemli örneği ABD'nin YPG/PYD'ye verdiği açık destek, ${ }^{[48]}$ yönlendirme ve talimatları oluşturmaktadır. ABD, YPG/PYD'nin gerçekleştirdiği insan hakları ihlalleri sebebi ile bu tasarının 8. maddesine göre sorumlu tutulabilecektir. YPG/PYD bu eylemlerini gerçekleştirirken, ABD'nin açık desteğini ve talimatlarını alarak eylemlerini gerçekleştirmekte olduğu için 2001 tarihli taslağın 8. maddesi amaca uygun yorumlanarak ABD'nin, terörü araç olarak kullanan YPG/PYD’nin insan hakları ihlallerinden sorumlu tutulabileceği sonucuna ulaşılabilmelidir.

Hatta terör eylemi olmamış olsa bile bir devletin, desteklediği DDSA'ların gerçekleştirdiği insan hakları ihlallerinden dolayı 8. maddeye göre sorumlu

\section{[45] YEŞİLTAŞ/DURAN, s.189.}

\section{[46] ERKINNER, s.309.}

[47] Responsibility of States for Internationally Wrongful Acts, with commentaries, s.39

[48] YPG/PYD-ABD işbirliği hususunda daha fazla bilgi için bkz. Siyaset Dergisi, “Türkiye - Suriye Sınırında ABD-PYD İşbirliğì”, Siyaset Dergisi, https://siyasetdergisi.com. tr/turkiye-suriye-sinirinda-abd-pyd-isbirligi/ (Erişim Tarihi: 25.10.2019). 
olması mümkündür. 8. madde bağlamında verilebilecek diğer bir örnek de Türkiye Cumhuriyeti'nin ÖSO'ya verdiği açık destek ${ }^{[49]}$ olabilir. Ancak ÖSO bir DDSA olmasına rağmen ${ }^{[50]}$, YPG/PYD'nin olduğu gibi terörü araç olarak kullanan bir yapılanma değildir. Diğer taraftan ÖSO'nun insan haklarını ihlal etmesi durumunda da Türkiye söz konusu maddeye göre sorumlu k1lınabilecektir.

\section{DDSA'ların Bizzat Sorumluluğu}

DDSA'ların bizzat sorumluluğu noktasında tasarının 10. maddesi düzleminde bir DDSA'nın devlet niteliğine bürünmüş olup olmaması sorumluluğun tayini açısından oldukça önem arz eder.

Tasarının 10. maddesi ${ }^{[51]}$ konuya farklı bir açıdan yaklaşmıştır. "Bir isyan hareketinin ya da benzerinin davranışı” başlığı altında söz konusu isyan hareketi yeni hükümet haline gelirse veya yeni bir devlet kurulması

[49] BBC News Türkçe, “Özgür Suriye Ordusu Nedir: 2011'den 2018'e Örgütün Yaşadığ1 Dönüşüm” https://www.bbc.com/turkce/haberler-dunya-42862756 (Erişim Tarihi: 20.11.2019).

[50] "Silahlı muhalefet açısından çok sayıda silahlı grup, 2011 sonrası ortaya çıssa da bu gruplar açısından en önemlisi Özgür Suriye Ordusu (ÖSO) olmuştur. Temmuz 2011'de kurulan ÖSO, hiyerarşik bir yapıya sahip olmaktan daha çok yerel grupların bir araya gelerek ÖSO flaması altında çatışmasıyla meydana çıkmış ve ilerleyen yıllarda örgüt içi ilişkiler önemli bir sorun olurken yerel grupların yerel talep ve hedefleri de önemini korumaya devam etmiştir. Örgüt, Suriye içerisindeki çatışmalara bağlı olarak dönem dönem etkinliğini kaybetse de kriz boyunca Suriye genelinde kesintisiz bir şekilde faaliyet göstermeye devam etmiş ... Suriye krizinin kaynağını Suriye yönetimi olarak gören bölgesel ve uluslararası aktörlerin desteğini elde etmiştir.” ÇAĞLAR Turan, AKSU Fuat: "Suriye Krizinde Aktörler, Uyuşmayan Talepler ve Çatışan Çözümler”, International Journal of Social Inquiry, C.12, S.2, Y.2019, s.512-513.

[51] 10. madde "bir isyan hareketinin ya da benzerinin davranışı" başlığı ile sorumluluğu şu şekilde düzenlemiştir:

"1. Devletin yeni hükümeti haline gelen bir isyan hareketinin davranışı, uluslararası hukuka göre bu Devletin fiili olarak kabul edilir.

2. Bir isyan hareketinin ya da benzerinin davranışı, daha evvelden mevcut bir Devletin ülkesinin bir kısmında ya da bunun idaresi altında olan bir toprakta yeni bir Devlet kurmaya ulaşmışsa, milletlerarası hukuka göre bu yeni Devletin fiili olarak kabul edilir. 3. Bu madde, 4. maddeden 9. maddeye kadar olan maddeler uyarınca, Devletin fiili olarak kabul edilmesi gereken bütün davranışların, bunlar herhangi bir biçimde isyan hareketinin davranışlarına bağlı olmuş olsa da, Devlete isnat edilmesine engel olmaz.”. 
durumunda bu eylemler devletin fiili olarak kabul edilecektir. (fikra 1, 2) Kaldı ki 10. maddenin şerhinde; bir DDSA'nın doğrudan hukuki sorumluluğuna gidilebileceği ihtimali üzerinde durulmuşsa da hemen ardından bu maddenin temelde aslında devletlerin sorumluluğunu düzenlediği ve bu ihtimalin mümkün görülmediği belirtilmiştir. ${ }^{[52]}$

Konu DEAŞ mivalinde değerlendirildiğinde, DEAŞ, kendi adlandırmalarının açılımından da anlaşılacağı üzere kendisini bir devlet olarak görmektedir. DEAŞ kendi varlığında tamamen bağımsız bir yapılanmadır. $\mathrm{Bu}$ açıdan DEAŞ’in insan hakları ihlallerinden doğan sorumluluğu doğrudan kendisinin sorumluluğu olarak karşımıza çıkmaktadır. DEAŞ; silahlı iç çatışma durumunun baş göstermesinden itibaren belli bir süre boyunca dini hukuku yani şeriat hükümlerini uygulayarak ve kodifiye ederek, resmi bir adalet sistemi oluşturarak, organize vergi tahsilatı ve örgün eğitim sistemi gibi yönetişim kalıpları oluşturma üzerinde çalışmışıır. ${ }^{[53]}$ Kullandığı yönetişim kalıplarına bakıldığında ise DEAŞ adeta bir devlet örgütlenmesi gibi faaliyet yürütmüştür. Kaldı ki isimlendirmelerini de "Irak Şam İslam Devleti” olarak belirlemişlerdir. DEAŞ; bölgesel güçlerin yani Türkiye, Özgür Suriye Ordusu ${ }^{[54]}$ ve ABD gibi aktörlerin etkin mücadelesi ile bölgesel ve yönetsel gücünü kaybetmiştir. Eğer güç kaybetmese ve devlet gibi varlığını devam ettirebilse idi tasarının 10. maddesine göre sorumluluğunun doğabileceğine yönelik bir sonuca varılabilirdi. Çünkü DEAŞ aslında bir devlet yapılanmasına sahipti ve eğer kendi konjonktüründe Suriye'de yeni devlet profilini devam ettirebilse idi 10. maddenin bu bağlamda uygulanabilirliğinin söz konusu olabileceği kanaatindeyiz.

Devlet dışı silahlı aktörler yukarıda da belirtildiği üzere 1990'lı yıllardan itibaren daha çok uluslararası ilişkilerin ve uluslararası hukukun alanına girmiştir. Buna karşın bugüne kadar devlet dışı silahlı aktörlere dair uluslararası hukukta bir düzenleme yoktur. Bununla birlikte DDSA’ların silahlı çatışma durumunda insan hakları hukuku bağlamında yükümlülükler altında

[52] Responsibility of States for Internationally Wrongful Acts, with commentaries, s.52

[53] YEŞİLTAŞ/DURAN, s.16.

[54] DEAŞ ile mücadeledeki konumu için bkz. Yenişafak, "Güç Kaybeden DEAŞ’den Yeni Strateji”, https://www.yenisafak.com/dunya/guc-kaybeden-daesden-yenistrateji-2485257, 22 Haziran 2016, (Erişim Tarihi: 1.12.2019). 
olup olmadıkları tartışmalı bir meseledir. ${ }^{[55]}$ Bu tartışmanın özü, DDSA'ları uymaları gerekli bir normla bağlı kılmanın bu aktörlerin varlığına meşruiyet verip vermemesi noktasındadır. ${ }^{[56]}$

Ancak terazinin bir kefesinde yaşanan yoğun insan hakları ihlallerinin ve bunların sorumlularının ortaya çıkarılması gerekliliğinin bulunması, diğer kefesinde de DDSA'lara meşruiyet kazandıran düzenlemelerin uluslararası hukukta oluşturulmaması gerekliliğine yönelik bir menfaat bulunması varsayımında hangi kefenin ağır basacağı ise tartışma konusu olabilmektedir.

Bazılarına göre devletin tüzel kişiliği dışındaki silahlı organizasyonları insan haklarını ihlal etmemek ve insan haklarına saygı duymak noktasında yükümlülük altına sokmak mümkündür; çünkü bu silahlı gruplar bulundukları toprakta ve bu toprakta yaşayan insan topluluğu üzerinde dikkate değer oranda kontrol sağlamakta ve siyasal bir yapı inşa etmektedirler. ${ }^{[57]}$ Uluslararası hukukta devlet artık uluslararası hukukun tek sujesi olmadığ için, devlet dışı silahlı aktörleri de insan hakları ihlallerinde bulunamama noktasında yükümlü kılmak uluslararası toplumun menfaatine olacaktır.

Bazılarına göre ise sadece devletler, insan haklarına uyma noktasında yükümlülük altında olabilir ve hukuken sorumluluk taşıyabilir. İnsan haklarına uyma yükümlülüğü sadece devletler üzerinde bağlayıcı olabilecektir. Uluslararası hukuk, DDSA'ları insan haklarını gözetmeye mecbur kılma aşamasına henüz ulaşmamıştır. DDSA'ların doğrudan sorumlu kılınmasına karşı gelenlerin üzerinde durduğu temel argüman; devletlere uygulanan hukuksal rejimin bir benzerinin DDSA’lara uygulanmasını sağlamanın bunların meşruluğunu arttırabileceğidir. Bu düşünceye paralel bir diğer düşünce ise insan haklarına uymaları noktasında yükümlülük yüklemek

[55] Academy in Brief No.7, "Geneva Academy of International Humanitarian Law and Human Rights, Human Rights Obligations of Armed Non-State Actors: An Exploration of the Practice of The UN Human Rights Council”, Aralık 2016, s.19, https://www.geneva-academy.ch/joomlatools-files/docman-files/InBrief7_web.pdf (Erişim Tarihi: 26.01.2020).

[56] CLAPHAM Andrew: The Rights and Responsibilities of Armed Non-State Actors: The Legal Landscape \& Issues Surrounding Engagement, February 2010, https:// repository.graduateinstitute.ch/record/16583/files/SSRN-id1569636..pdf (Erişim Tarihi: 27.10.2019).

[57] CLAPHAM, s.27. 
için onlara yardımda bulunmanın veya çağrı yapmanın, teröre yardım ve yataklık yapma gibi bir çağrışım yaratabileceğidir. ${ }^{[58]}$

DDSA'ları gerçekleştirdikleri insan hakları ihlallerinden sorumlu kılmanın onları meşru kılacağı görüşüne rağmen, DDSA'ların insan haklarını gözetmekle yükümlü olması gerektiğinin desteklendiği uygulamalarla karşılaşmaktayız. Örnek vermek gerekirse BM Uluslararası Soruşturma Komisyonu DDSA'ları bağlayan teamül hukuku kurallarının bir listesini düzenlemiştir. BM Darfur Konusunda Uluslararası Soruşturma Komisyonu Raporu’nda uygulanması gereken başlıca örfi hukuk normları arasında şunları saymıştır: Sivillerle savaşçılar arasında ayrım ilkesi; sivillere kasıtlı saldırı yasağı; sivilleri terörize etmeyi amaçlayan saldırı yasağı; işkence, gayriinsani ya da kötü muamele yasağı; sivillerin zorla göç ettirilmesi yasağı; rehin alma yasağı; yağma yasağı; sivillere ayırım gözetmeyen saldırı yasağı; düşman savaşçılara kötü muamele yasağı; çatışma dışı kalmış kişilere insani muamele yükümlülüğü; kültürel bina ve nesnelere saldırı yasağı. ${ }^{[59]}$ BM'nin Uluslararası Soruşturma Komisyonu vasıtasıyla böyle bir liste oluşturması, DDSA'ların insan hakları ihlallerinden sorumlu tutulması gerekliliğine yönelik tavrını göstermektedir. Nitekim BM Genel Kurulu ve Güvenlik Konseyi DDSA'ların silâhlı çatışma sırasında insan hakları ihlalleri dolayısıyla sorumlu olduğuna dair bir uygulamayı desteklemektedir. ${ }^{[60]}$

Yukarıda anlatılanlara ek olarak, Suriye Konusundaki Bağımsız Uluslararası Soruşturma Komisyonu da Ağustos 2012 tarihli üçüncü raporunda sorumluluğun, etkin ve fiili kontrolü kim sağlıyorsa ona ait olduğunu belirtmiştir. Ayrıca, DDSA'ların uluslararası insan hakları hukuku ile bağlı olmasını ve bu kurallara saygı duyması gerekliliği açık şekilde vurgulanmıştır. ${ }^{[61]}$ Sonuç

[58] CLAPHAM, s.22-28.

[59] Report of the International Commission of Inquiry on Darfur to the United Nations Secretary-General- Pursuant to Security Council Resolution 1564 of 18 September 2004, Geneva, 25 January 2005, para. 166, http://www.un.org/news/dh/sudan/ com_inq_darfur.pdf (Erişim Tarihi: 28.12.2019).

[60] RODENHAUSER Tilman: International Legal Obligations of Armed Opposition Groups in Syria, International Review of Law, 2015:2, https://papers.ssrn.com/sol3/ papers.cfm?abstract_id=2604522 (Erişim Tarihi: 28.12.2019).

[61] Report of The Independent International Commission of Inquiry on The Syrian Arab Republic, August 2012. s.22-24, https://www.ohchr.org/Documents/HRBodies/ 
olarak söylenebilir ki, uluslararası hukuk zemininde BM, organları vasıtasıyla DDSA'ların insan hakları hukukuna uymaları gerektiğine yönelik bir uygulamayı desteklemektedir. Bir oluşum uluslararası bir normla bağlı olsa bile bu durum o oluşumun yasal ve meşru bir statüye girdiği anlamına gelmeyecektir. Zira 1949 Cenevre Konvansiyonu'nun 3. maddesi[ ${ }^{[62]}$ bu yargının temelini ortaya koymaktadır. Söz konusu düzenleme doğrultusunda DDSA'ları uluslararası insan hakları hukuku ile yükümlülük altına sokmanın, onlara meşruiyet kazandırmayacağı sonucuna varabiliriz. ${ }^{[63]}$

Sonuç olarak, bir DDSA insan hakları hukukuna uymaya zorlandığı için meşruiyet kazanmış olmayacaktır. DDSA’ları meşru görmemek onların varlığı realitesini kendiliğinden ortadan kaldırmayacağı için bunları yükümlülük altına sokmak da onları doğrudan uluslararası hukukun süjelerinden birisi yapmayacaktır. ${ }^{[64]}$ Uluslararası hukuk bu gibi tartışmalı hususlara yönelik teori oluşturmada henüz olması gereken seviyede olmamasına rağmen, 1992 tarihli Boutros Boutros-Ghali'nin hazırladığ 1 Agenda for Peace Raporu'nda yer alan önleyici diplomasi modeli gibi argümanlar ${ }^{[65]}$ kullanılarak mevcut uluslararası insan hakları hukuku sorunu çözüme kavuşturulabilir. Ayrıca etkin otorite yokluğunun giderilmesine yönelik devletlere destek verme

HRCouncil/RegularSession/Session21/A-HRC-21-50_en.pdf (Erişim Tarihi: 20.01.2020).

[62] Common Article 3, $\$ 2$, of the Geneva Conventions states: '.. The application of the preceding provisions shall not affect the legal status of the Parties to the conflict.'

[63] Academy in Brief No.7, s.31-32.

[64] "Uluslararası hukukta sujenin belirlenmesi, uluslararası toplumun gereksinimleri ile yükümlülük ve haklar edinebilme düzeyine bağlıdır. Diğer bir deyişle, sujenin belirlenmesi, rastgele ve kendiliğinden oluşan bir durum değil, gerekli koG̣ulların yerine getirilmesi halinde gerçekleşen bir durumdur." AZARKAN Ezeli: "Bireyin Uluslararası Cezai Sorumluluğu ve Miloseviç Davası”, Selçuk Üniversitesi Hukuk Fakültesi Dergisi, C.11, S.3-4, Y.2003, s.266.

[65] Önleyici diplomasi, taraflar arasında ihtilafların ortaya çıkmasını önlemek, mevcut ihtilafların çatışmalara dönüşmesini önlemek ve ortaya çıktığında yayılmasını sınırlamak için yapılan eylemdir . Bkz. Report of the Secretary-General pursuant to the statement adopted by the Summit Meeting of the Security Council on 31 January 1992, An Agenda for Peace Preventive diplomacy, peacemaking and peace-keeping, para.20. 
misyonunda uluslararası örgüt kurulması gibi yeni oluşumlar da insan hakları ihlallerinin giderilmesinde dolaylı olarak etkili olabilecektir.

\section{SONUÇ VE DEĞERLENDIRME}

Uluslararası hukukta aktör kavramının değişim süreci ile devletlerin ve uluslararası örgütlerin artık insan hakları ihlalleri konusunda uluslararası hukukun yegâne süjesi olmadığının farkına varılmıştır. Uluslararası hukukta devletleri ve devlet dışı aktörleri insan hakları ihlallerinden sorumlu tutma mekanizmalarının oluşturulması hususunda çalışmalar yapılması, uluslararası hukukun dinamik yapısının en önemli yansımalarından biri olmuştur. Uluslararası hukuk, değişen ve gelişen dünya düzeninde doğan ihtiyaçlara cevap verebilecek olgunluğa erişmede henüz olması gereken noktada olmamasına rağmen büyük bir gelişim süreci gerçekleştirmiştir. Özellikle BM Uluslararası Hukuk Komisyonu' nun 2001 yılında devletlerin sorumluluğu hususundaki teamüllerden oluşan dağınık hukuki düzenlemeleri kodifiye ettiği Devletlerin Uluslararası Hukuka Aykırı Fiillerden Sorumluluğu’na ilişkin tasarı uluslararası hukukta devletin ve devlet dışı aktörlerin sorumluluğu açısından önemli bir köşe taşı olmuştur.

8. ve 9. maddeleri başta olmak üzere genel olarak tasarı, özellikle Suriye devletindeki etkin otorite yokluğunda olması gerekene yönelik çok değerli düzenlemeler içermektedir. Bölgesel aktörler dışında kalan devletler, devlet dışı silahlı aktörleri siyasi ve mali açıdan destekleyerek dolaylı olarak insan hakları ihlallerinde bulunmuş olacaklardır. Bunun engellenmesi ve bu devletlerin sorumlu kılınabilmesi adına tasarı etkili bir sorumluluk mekanizması öngörmekte; fakat DDSA’ların gerçekleştirdiği insan hakları ihlallerinde devletin ve DDSA'ların doğrudan sorumluluğunu açıkça düzenlememektedir. Akıl yürütme metodu ile ilgili tasarı hükümlerinin DDSA'ların fiillerinde de uygulanabilmesinin sağlanması ile bu eksikliğin giderilmesi mümkün olabilecektir. Ancak insan haklarının korunması adına salt hukuki düzenlemelerle yetinilmesinin teoride uluslararası hukukun gelişimine katkı sağlamakla birlikte pratikte ihlalleri önleme konusunda yeterli olmayacağı da açıktır.

DDSA'ların gerçekleştirdiği insan hakları ihlallerinden, ihlalin gerçekleştiği devletin sorumluluğu hususu çalışmada önem arz eden konulardan biridir. Etkin otorite yokluğunda DDSA'nın eylemlerinden devletin sorumlu kılındığı 9. madde ile Boilvar-Railway Company Davası'nda verilen karar ve AİHM'nin Loizidou davasında verdiği karar arasındaki farklılık dikkat 
çekmektedir. Kınanabilirlik kriteri bağlamında, etkin otoritesi bulunmayan devletin, DDSA'ların fiillerinden sorumlu olmayacağı sonucuna ulaşılmıştır. Teamül hukukunun derlemesi niteliğindeki tasarıda DDSA'nın fiilinden devleti sorumlu kılan 9. maddenin aslında etkin otorite yokluğunda olması gereken hukuku yansıtmadığı ve teamül kuralına dayanmadığı tespitinde bulunulmuştur.

Dünya devletlerinin, ekonomik çıkarlarını korumak amaçlı kurdukları Uluslararası Para Fonu (IMF) alınması gereken insiyatifler hususunda yol gösterici olabilecek niteliktedir. Çünkü IMF'nin kurulma saiklerinden birisi; bir devletin ekonomik kriz ortamına girmesinin, o devletle ticari münasebetlerde bulunan diğer devletlerin de ekonomisini bozacak olması ve iktisat bilimi doktrininde mevcut sürükleme hipotezi çerçevesinde bunun bir domino etkisi yaratacağı düşüncesidir. Kaldı ki bunun en önemli örneğini 1929 Buhranı oluşturmaktadır. Aynı mantık, etkili devlet yönetimi yetisini kaybeden devletin fillerinin diğer devletleri de etkileyebilecek olması hususunda kendisini gösterebilir niteliktedir. Suriye' nin etkili devlet yönetimi yetisini kaybetmesi, DEAŞ ve YPG/PYD gibi terör örgütlerinin doğmasına yol açmıştır. Ve bu örgütlerin fiilleri neticesinde birçok insan ağır insan hakları ihlallerine maruz kalmıştır. DEAŞ, Irak Devletini ve Şam şehrini kendisine merkez edinerek yönetsel faaliyetlerde bulunmuş ve insan haklarını bölgesel düzeyde ihlal etmekle kalmayıp, ihlallerini küresel düzeyde de gerçekleştirmiştir. Bu ihlallerden en çok zarar gören devletlerden birisi de Suriye’nin sınır komşusu olan Türkiye olmuştur. Buradan hareket ile IMF gibi uluslararası bir organizasyon oluşturulursa, bu organizasyonun etkili devlet yönetimini kaybeden devletlere siyasi ve askeri olarak yardım etmesi sayesinde, ülkesinde etkili devlet yönetimi yetisini kaybeden devletlerin bu yetisini geri kazanmaları sağlanabilecektir. Bu sayede uluslararası menfaat de korunmuş olacaktır. Böylesi bir uluslararası mekanizma oluşturmak suretiyle insan hakları ihlallerini tespiti mümkün olacaktır. Uluslararası camiada kamuoyu oluşturma etkisi bakımından ihlallerin hukuki sorumlularını tespit etme, büyük bir amaca hizmet edecektir. Özellikle emperyalist ideadan kendisini soyutlayamamış güçlü devletlerin DDSA'larla işbirliği yaparak teröre destek faaliyetlerinin açığa çıkarılması, en azından uluslararası camiada farkındalık yaratacaktır. Ancak yine de emperyalist devletlerin faydasına olmayacak düzeyde bir koruma mekanizmasının yaratılması ve hassas dengenin oluşturulması da büyük önem arz edecektir. 
Devlet dışı silahlı aktörlerin hukuki sorumluluğuna gidilebilmesi, özellikle Suriye'nin siyasi ve coğrafi konjonktüründe büyük bir güçlük arz etmektedir. Bununla beraber eğer insan hakları ihlallerinin sorumluları ortaya çıkarılmazsa uluslararası menfaat ihlal edilmiş olacaktır. DDSA'ların varlığını ve eylemlerini kınamanın tek başına yeterli bir tepki olmayacağından hareket ile uluslararası hukuk mekanizmaları işlevselleştirilip ortak bir tepki mekanizmasını yaratma hususunda kollektif insiyatif alınması, insan hakları ihlallerinin engellenmesinde büyük öneme sahip olacaktır. Bu hususta DDSA'lara meşruiyet kazandırmayacak hassaslıkta, özellikle Suriye siyasi iç krizinde mevcut insanlık krizine çözüm bulmak için devletlerin sahip oldukları etkili diplomasi olanaklarını kullanmaları gerekmektedir. Böylece hem insan hakları ihlallerinin sorumluları açığa çıkmış olacak hem de DDSA'lar, insan haklarını ihlal etmeme noktasında belirli bir yükümlülüğe sokulabilecektir. 


\section{KAYNAKÇA}

28 Eylül 2016 tarihli MGK Basın Bildirisi, para.5, http://www.mgk.gov. tr/index. php/28-eyluel-2016-tarihli-toplantı (Erişim Tarihi: 20.10.2020).

Academy in Brief No.7, Geneva Academy of International Humanitarian Law and Human Rights, Human Rights Obligations of Armed Non-State Actors: An Exploration of the Practice of The UN Human Rights Council, Aralık 2016 https:/www.geneva-academy.ch/joomlatools-files/docman-files/ InBrief7_web.pdf (Erişim Tarihi: 26.01.2020).

ACER Yücel ve KAYA İbrahim: Uluslararası Hukuk Temel Ders Kitabı, Seçkin Yayıncılık, 10. Bası, Ankara 2019.

AKPINARLI Neyire: Fragility of the 'Failed State' Paradigm, Martinus Nijhoff Publishers, Leiden Boston, 2010, s.7

ALGAN Bülent, IŞIK Salim: Ulusal İnsan Hakları Mekanizmaları Mevzuatı, Savaş Yayınevi, Ankara, 2016.

Amnesty International, Syria: US Ally's Razing of Villages Amounts to War Crimes, October 132015 https:/www.amnesty.org/en/latest/news/2015/10/ syria-us-allys-razing-of-villages-amounts-to-war-crimes/ (Erişim Tarihi: 1.1.2020).

AZARKAN Ezeli: "Bireyin Uluslararası Cezai Sorumluluğu ve Miloseviç Davası”, Selçuk Üniversitesi Hukuk Fakültesi Dergisi, C.11, S.3-4, Y.2003, ss.265-287.

BAL Ali: Devletin Uluslararası Sorumluluğunun Doğması, Dokul Eylül Üniversitesi Kamu Hukuku Yüksek Lisans Tezi, 2006 http://acikerisim. deu.edu.tr:8080/xmlui/bitstream/handle/20.500.12397/11843/189480. pdf?sequence $=1$ \&isAllowed $=y$ (Erişim Tarihi: 25.1.2020).

BBC News Türkçe, Özgür Suriye Ordusu Nedir: 2011'den 2018'e Örgütün Yaşadığı Dönüşüm, 30 Ocak 2018 https://www.bbc.com/turkce/haberler-dunya-42862756 (Erişim Tarihi: 20.11.2019). 
Birleşmiş Milletler Genel Kurulu İnsan Hakları Konseyi 16 Ağustos 2012 Tarihli Raporu, https://www.ohchr.org/Documents/HRBodies/HRCouncil/RegularSession/Session21/A-HRC-21-50_en.pdf (Erişim Tarihi: 20.01.2020).

CAN Mücella: “İnsan Hakları ve Demokrasi Arasındaki İlişkinin Felsefi Analizi” Atatürk Üniversitesi Sosyal Bilimler Enstitüsü Dergisi, C.23 S.4, Y.2019, ss.2155-2167.

CLAPHAM Andrew: The Rights and Responsibilities of Armed NonState Actors: The Legal Landscape \& Issues Surrounding Engagement, February 2010, https://repository.graduateinstitute.ch/record/16583/files/ SSRN-id1569636.pdf (Erişim Tarihi: 27.10.2019).

ÇAĞLAR Turan, AKSU Fuat: "Suriye Krizinde Aktörler, Uyuşmayan Talepler ve Çatışan Çözümler”, International Journal of Social Inquiry, C.12, S.2, Y.2019, ss.507-544.

ÇEÇEN Anıl: "İnsan Hakları ve İnsancıl Hukuk", Yaşar Hukuk Dergisi, C:8 Özel Sayı, 809-830.

D'ASPREMONT Jean, NOLLKAEMPER Andre', PLAKOKEFALOS Ilias; RYNGAERT Cedric: "Sharing Responsibility Between Non-State Actors and States in International Law: Introduction", Neth Int Law Rev (2015) 62:49-67, https://link.springer.com/article/10.1007/s40802-015-0015-0 (Erişim Tarihi: 19.11.2019).

DEREBOYLULAR Özde ve ARMAN Perçem: Avrupa İnsan Hakları Mahkemesinin Kıbrısla İlgili Verdiği Kararların KKTC ve Türkiye’ye Etkisi, TBB Dergisi Yıl: 2018, Sayı: 136, http://tbbdergisi.barobirlik.org.tr/m2018136-1777 (Erişim Tarihi: 29.10.2019).

Draft Articles On Responsibility Of States for Internationally Wrongful Acts, With Commentaries, Yearbook Of The International Law Commıssion, 2001, Volume II, Part 2, https://legal.un.org/ilc/publications/yearbooks/ english/ilc_2001_v2_p2.pdf (Erişim Tarihi: 11.11.2019).

ERKINNER Hakkı Hakan: Devletin Haksız Fiilden Kaynaklanan Uluslararası Sorumluluğu, Oniki Levha Yayınları, Ankara 2010. 
Hass and Priebke case in 1997, https://ihl-databases.icrc.org/applic/ihl/ ihl-nat.nsf/0/83344FFD0508802AC125765B004B9E54 (Erișim Tarihi: 20.10.2020).

HEHIR Aidan: Humanitarian Intervention: An Introduction, Hampshire, Palgrave Macmillan, 2010.

HOUGHTON N.D. "The Responsibility of the State for the Acts and Obligations of Local De Facto Governments and Revolutionists", Minnesota Law Review, 1990, s.253, https://core.ac.uk/download/pdf/217207587 (Erişim Tarihi: 20.10.2020).

Loizidou v. Turkey, Report of the Commission, adopted on 8 July 1993. http://www.hudoc.echr.coe.int (Erişim Tarihi: 20.10.2020).

LOWE Vaughan: International Law, Clarendon Law Series, Oxford: Oxford University Press, 2007.

Montevideo Convention, https://www.ilsa.org/Jessup/Jessup15/Montevideo\%20Convention.pdf (Erişim Tarihi: 28.10.2019).

ÖĞÜT Selman: "Başarısız Devlet Kavramının İncelenmesi”, Marmara Üniversitesi Hukuk Fakültesi Hukuk Araştırmaları Dergisi, C.19, S.3, Y.2013, s.163-177.

PROVOST Rene: International Human Rights and Humanitarian Law, Cambridge University Press, Cambridge, 2004.

Report of The Independent International Commission of Inquiry on The Syrian Arab Republic, August 2012. s.22-24, https://www.ohchr. org/Documents/HRBodies/HRCouncil/RegularSession/Session21/AHRC-21-50_en.pdf (Erişim Tarihi: 20.01.2020).

Report of the International Commission of Inquiry on Darfur to the United Nations Secretary-General- Pursuant to Security Council Resolution 1564 of 18 September 2004, Geneva, 25 January 2005, http://www. un.org/news/dh/sudan/com_inq_darfur.pdf (Erişim Tarihi: 28.12.2019). 
Report of the Secretary-General pursuant to the statement adopted by the Summit Meeting of the Security Council on 31 January 1992, para.43, https://www.un.org/ruleoflaw/files/A_47_277.pdf (Erişim Tarihi: 21.10.2020).

Report of the Secretary-General pursuant to the statement adopted by the Summit Meeting of the Security Council on 31 January 1992, An Agenda for Peace Preventive diplomacy, peacemaking and peace-keeping. https:// www.un.org/ruleoflaw/files/A_47_277.pdf (Erişim Tarihi: 20.10.2020).

RODENHAUSER Tilman: International Legal Obligations of Armed Opposition Groups in Syria, International Review of Law, 2015:2, https:// papers.ssrn.com/sol3/papers.cfm?abstract_id=2604522 (Erişim Tarihi: 28.12.2019).

ROTBERG Robert I.: State Failure and State Weakness in a Time of Terror, World Peace Foundation Brookings Institution Press, Cambridge, Massachusetts, 2003.

Syria: US ally's razing of villages amounts to war crimes, https://www. amnesty.org/en/latest/news/2015/10/syria-us-allys-razing-of-villagesamounts-to-war-crimes/, October 2015, (Erişim Tarihi: 1.1.2020).

TAŞDEMİR Fatma: "Devlet Merkezli Uluslararası Hukuk Sistemi Ve Devlet Dışı Silâhlı Aktörler”, İ.Ü. Siyasal Bilgiler Fakültesi Dergisi, No:56, Mart 2017, ss.59-85.

Türkiye - Suriye Sınırında ABD-PYD İşbirliği, Eylül 2019 Siyaset Dergisi İnternet Yazısı. https://siyasetdergisi.com.tr/turkiye-suriye-sinirinda-abdpyd-isbirligi/ (Erişim Tarihi: 25.10.2019).

YAŞAR Ali: İbni Haldun'a Göre Siyasi Otorite ve Liderlik, Genç Hukukçular Hukuk Okumaları, s.2. http://www.muharrembalci.com/hukukdunyasi/makaleler/birikimlerV/610.pdf (Erişim Tarihi: 20.12.2019).

Yenişafak, "Güç Kaybeden DEAŞ’den Yeni Strateji”, https://www.yenisafak.com/dunya/guc-kaybeden-daesden-yeni-strateji-2485257, 22 Haziran 2016, (Erişim Tarihi: 1.12.2019). 
YEŞİLTAŞ Murat ve DURAN Burhanettin: Ortadoğu'da Devlet dışı silahlı Aktörler, Seta Kitapları, İstanbul 2018.

ZAFER Hamide: Ceza Hukuku Genel Hükümler (TCK m. 1-75), Beta Yayıncılık, 7. Baskı, İstanbul 2019. 
